Right Honourable Brian Mulroney Prime Minister

House of Commons

Ottawa, Ontario

K1A 0A6

Dear Mr. Prime Minister:

Mr. Harry Gairns, then President of the Canadian Institute of Forestry/ Institut Forestier du Canada (CIF/IFC) wrote to you in September 1990 to express our support for a World Forestry Convention and the creation of a new separate World Forestry Organization, headquartered in Canada.

Your response indicated support for the World Forestry Convention which is well underway. We have been pleased to be able to provide assistance and input into this document through the auspices of the Government of Canada and, in particular, through Forestry Canada.

With regard to the creation of a separate World Forestry Organization, you suggested that careful examination of existing international arrangements and financial resources available would be required. With this suggestion in mind, I have attached a copy of a paper prepared by members of our Institute and published in our professional journal, The Forestry Chronicle. This paper examines world forest resources, existing structures and trends in support for forestry worldwide. The paper also suggests options for a new institutional structure for world forestry activities.

The CIF/IFC strongly supports the creation of a World Forestry Organization and sees this as a natural flow from the World Forestry Convention being prepared for UNCED ' 92 . The creation of this organization would result in the formation of a group to act as secretariat to the international instrument. This new organization could implement items on Agenda 21 on Forests and could coordinate the efforts of ITTO, FAO, UNIDO, UNESCO and other international organizations and activities as well.

For many reasons we believe that Canada is the best country in the world for the headquarters of this World Forestry Organization. Canada is recognized internationally as a mid-power country and respected as a bridge between developed and developing countries. Canada, and Canadians, have

well established international credibility. We have internationally respected forestry institutions such as Forestry Canada, our Technical schools and universities that teach forestry and other pertinent subjects such as ecology, wildlife management, and, yes, economics and business management. We have forestry people who can work in not only English and French, official languages of Canada but also, due in part to our multicultural approach, many other languages as well. It is also advantageous that both of Canada's official languages, together with Arabic, Chinese, Russian and Spanish are ones in which the United Nations Agenda 21 on Forests will be officially written.

The approximately $40 \%$ of Canada's land area that is forested comprises some $10 \%$ of the world total. Canada has committed itself to retain $12 \%$ of its total forested area in a protected state, in accordance with this expressed need in "Our Common Future". We have, in the view of the CIF/IFC, some of the best forest management in the world and are working hard to make it

\title{
Section News/Nouvelles des Sections
}

\section{Central Ontario}

Dec. 12, 1991 Section Meeting

The theme of this meeting was Community Forests and Model Forests.

Paul Addision (Forestry Canada Ontario Region) gave an overview of the federal Green Plan. Two of the seventyseven initiatives in the Green Plan Pertain to forestry: Partners in Sustainable Development of Forestry and Model Forests.

Model Forests are intended to be working examples of sustainable development. The aim is to create six to nine Model Forests in the major forest regions of Canada. Examples of areas in Ontario for which Model Forest proposals are being prepared include: Algonquin Park; a southern Ontario combination of Oak Ridges moraine / Niagara escarpment / Carolinian forest; town of Geraldton community forest; Boise Cascade limits; Kapuskasing / Smooth Rock Falls Hwy 11 corridor; and Temagami.

Steven Harvey (Policy Section of the Ontario Ministry of Natural Resources) outlined OMNR initiatives in Sustainable Forestry.

The Sustainable Forestry initiative incorporates: a forest audit; a comprehensive forest policy framework; silviculture R\&D; even better through efforts such as the National Forest Strategy for Canada and the Green Plan. The current work to develop a set of Codes for Forestry Professionals and to establish model forests are two concrete examples.

The CIF/IFC believes this to be an opportune time for Canada to promote, at the highest international level, the concept of a World Forestry Organization. We urge that, as part of Canada's proposal at UNCED '92 in Brazil, you announce Canada's intention to pursue the creation of a separate World Forestry Organization, to be headquartered in Canada. This would be seen as our nation taking a bold step forward in acting upon the statements contained in the World Forestry Convention and wishing to move world forestry ahead. CIF/IFC would provide you with its full support for this endeavour.

\section{Sincerely, \\ Arden Whidden President}

Editors note: A similar letter was also sent to the Right Honourable Barbara MacDougall, Secretary of State for External Affairs. 
regarding TFL AAC cuts in TFLs 44, 46 and 54), explaining the difficulty in filing his story by his deadline of 4:00 p.m., when the press announcement by the Ministry of Forests was made at 2:00 p.m.! He is unable to get any meaningful input out on the first day of the story, and by the second day, old news is no news (or Section E third page news, instead of Front page news). He views the forestry land use challenge as the creation of a process that provides for meaningful input for a larger group of people.

Lucie McNeill, the host of the open line CBC Radio show, Almanac, has spent ten years in journalism, and has an academic background in agricultural economics. Lucy would love to hear from people, and encouraged the group to be more proactive; i.e., call in to her and other journalists, write her letters, send her business cards, or go for lunch with her (she does not accept free lunches!). In her program, she tries to make things interesting by exploring tensions between people. She reiterated the idea that the nature of news is what's happening right now - the shelf-life of a story is very short, and if people are reluctant to comment on a story immediately (even if they have not totally analyzed the situation) their perspective may not get told.

Ian Gill, CBC-TV, Natural Resources, suggested to the CIF forestry audience that they examine the reasons why they want better relations with the media - is it to sell ideas or sell themselves (if so, go out and buy advertisements), or is it to influence the media (if so, slip them a story - be a whistle-blower), or do they have something to say (i.e. a story!). Ian likened the media to fish eating shrimp - We feed, we move on! He feels that foresters need to be proactive amongst themselves, and that the debate should be carried on from within. His advice was to listen, watch, and read to determine who are the journalists 'on the beat' that are working seriously on the issues and want to be reasonable and improve social understanding. He warned against expecting too much of the media; they have limitations just like everyone else. On the debate of whether the forestry community should be defensive or offensive, he suggested that being defensive may liken them to a politician! (Aak!) His guiding words in dealing with the media were to be honest.

A discussion period, heated at times, followed the presentations.

From Vancouver Section Update February 1992

\section{Vancouver Island}

\section{Forestry Scholarship}

At the February 12, 1992 meeting of the Vancouver Island Section, the Annual Forestry Scholarship of $\$ 250.00$ was presented

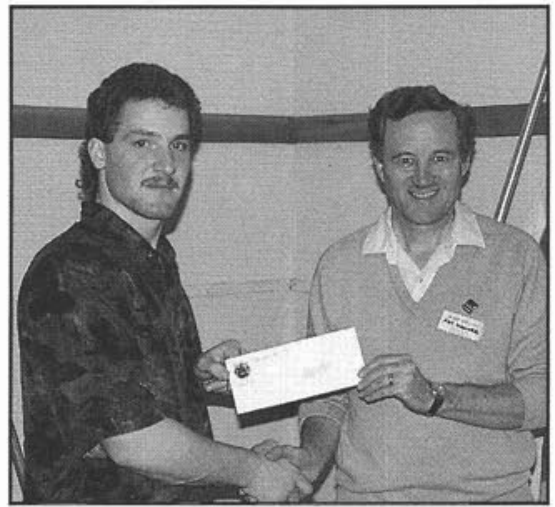

Clint Cadwallader (l.) being presented with Annual Forestry Scholarship cheque by Art Walker, Section Vice-Chairman.

to Malaspina College student Clint Cadwallader.

The Scholarship recognizes a student in the second year of the Forest Resources Technology program of Malaspina College in Nanaimo, who combines a high grade point average with a background in the forest industry.

\section{Art Walker, R.P.F.}

\section{Cowichan Valley Demonstration Forest}

What's new in your Demonstration Forest? (for your information the CIF South Island Section was a founding member of the Demonstration Forest).

Over the past several years there have been continued improvements to the Demonstration Forest. In 1987-88 the Youbou Deer Winter Range Trail was constructed. The project was undertaken by the Ministry of Environment, IWIFR program, using funds from the Habitat Conservation Fund. This program also was the major contributor to the first Green Gold Grant. The Green Gold Grants are provided under the Canada-British Columbia Forest Resource Development Agreements, FRDA and FRDA II. To date the Demonstration Forest has received 5 such Grants. The Grants are listed below:

1. New Brochure

2. Nature Trail Guide Brochure

3. Highway Information Signs

4. Nature Trail Signs

5. Driving Tour Guide Brochure

The total value of the Grants is $\$ 20,000.00$. Each Grant provides a maximum of $50 \%$ of the funding for each project. The Demonstration Forest matched and exceeded the Grants by providing inkind improvements, volunteer time and labour, and by using funds from the participants.

The Demonstration Forest has benefitted from on going job creation programs such as FEP, sponsored by the Ministry of Forests and the Muncipality of North Cowi- chan. These crews have performed most of the maintenance and repairs required on the Upper Viewpoint and Nature Trail.

The Demonstration Forest has participated in the Cowichan and Chemainus Valley Ecomuseum since its inception. In the summer of 1990 weekly tours of the Forest were held in cojunction with other Ecomuseum tours.

At present the Demonstration Forest is preparing to apply for funding of up to 1 million dollars in the Model Forest Program. This program is designed to provide 8-15 high profile Model Forests across Canada. The funding will allow the Demonstration Forest to hire part-time help and improve its' value as an educational tool.

You can support the Demonstration Forest by using it, showing it to others, supporting the Model Forest application, and by joining the volunteer Cowichan Valley Demonstration Forest Action Group. For more information contact CIF council member Kelly Schellenberg.

\section{Don Avis} Secretary/Treasurer

\section{Maritime}

"The Forest Sector in Crisis - A Climate for Change"' was the title of a day-long seminar at Sylvicon'92 held at the new Sheraton Inn, Fredericton, on February 18-19.

A total of nine speakers representing the forest products industries, the woodlot owners, labour, academics as well as the federal and provincial governments presented, as you would expect, a wide range of views. Although the viewpoints differed greatly there was, at the end of the day, a realisation that all concerned must work together to resolve the forest sector's problems so that we can continue to compete in the global market.

Although it has been recognised for decades that Canada must, for its economic health, export its goods and services on the basis of quality and price, there is a third and increasingly important dimension - our care of the environment. Those companies trading in the European market are now being quizzed on their actions to protect the environment from degradation.

From the forestry perspective, not only must our forest management practices be above reproach but they must be seen to be above reproach by the citizens of this country. There are, we were told, "Canadians (who are) telling Europeans not to buy Canadian products". Public awareness of what is actually going on in the forest is absolutely essential as Joe O'Neill of the Miramichi knows only too well. Joe was the recipient of the K.L. Golding Award, presented to him by the Canadian Forestry Association of N.B. as well as the CIF/IFC Tree of Life Award for his pioneer work in 
the area of public education and awareness.

At the Section's A.G.M. Bob Dick, the outgoing Chairman, reported on an another active year. In response to a request from members in north-western N.B., the Section Council established a regiocal committee tho foster C.I.F.J.F.C. goals at the local level ${ }^{H .}$. Guy Caron was named the Section member of the Year in recognition of organising the N.W, rogional committee at Edmundston. This is the home of the University of Moncton's French language forestry programme.

Peter Etheridge, as the incoming chairman, took over the helm shortly before the close of the A.G.M. and emphasized his intention to seek out new members. Ted Needham was elected to the position of Vice-Chairman, while messrs, Doug Prosser, Gilles Coutourier and Jerry Dunlap will be the newcomers on the Section Council. The ever-competeat Dr. Dave McLean will continue as secretary/treasurer.

The two concluding informal meetings, under the heading "Environmental Impact in Forestry - The New Wave," will be held in March and April at the University Club, U.N.B. These will be reported on in due course.

With the cenoming forest fire season, may all your fires be litsle ones.

Bob Spunwry

\section{Orleans}

\section{Bilan d'un étế chand}

Le 29 janvier dernier, se tenait à Sainte Foy, la deuxième d'une série de rencontres organisbes par la soction Orlkans de l'Institut forestier du Canada, portant sur des sujets d'actualitis forestieres au Quebec. Cette fois, les discussions ont porté sur différentes faceties des incendies de foréts qui sont suryenues sur la Cồte Nord au cours de l'éte 1991.

Quelque 65 personnes ont assisté aax conférences prononcées par Messieurs Régis Proulx et Jean Brunet, respectivement chef du Service de protection contre le feu et directeur de la gestion des stocks forestiers au Ministère des Forêts du QuCbec, ainsi que par le Dr. Rejean Gagnon, chercheur à I'Université du Québec à Chicoutimi. Le Dr. Gilles Frisque, directeur du Centre Multi-rtégional de foresterie de I'Universiné du Quebec, agissait à titre de modérateur.

Monsieur Proulx a d'abord traité des aspects physique, logistique, médiatique ef politique reliés à l"extinction de ces grands feux. Pendant un mois, le personel du Service de protection contre le feu a travaille à un train d'enfer: gestion des ressources humaines et matérielles, evacuation de vil. lages, limitation de l'accès à la forét au plus fort de la saison touristique, organisation des conférences de presse, etc.

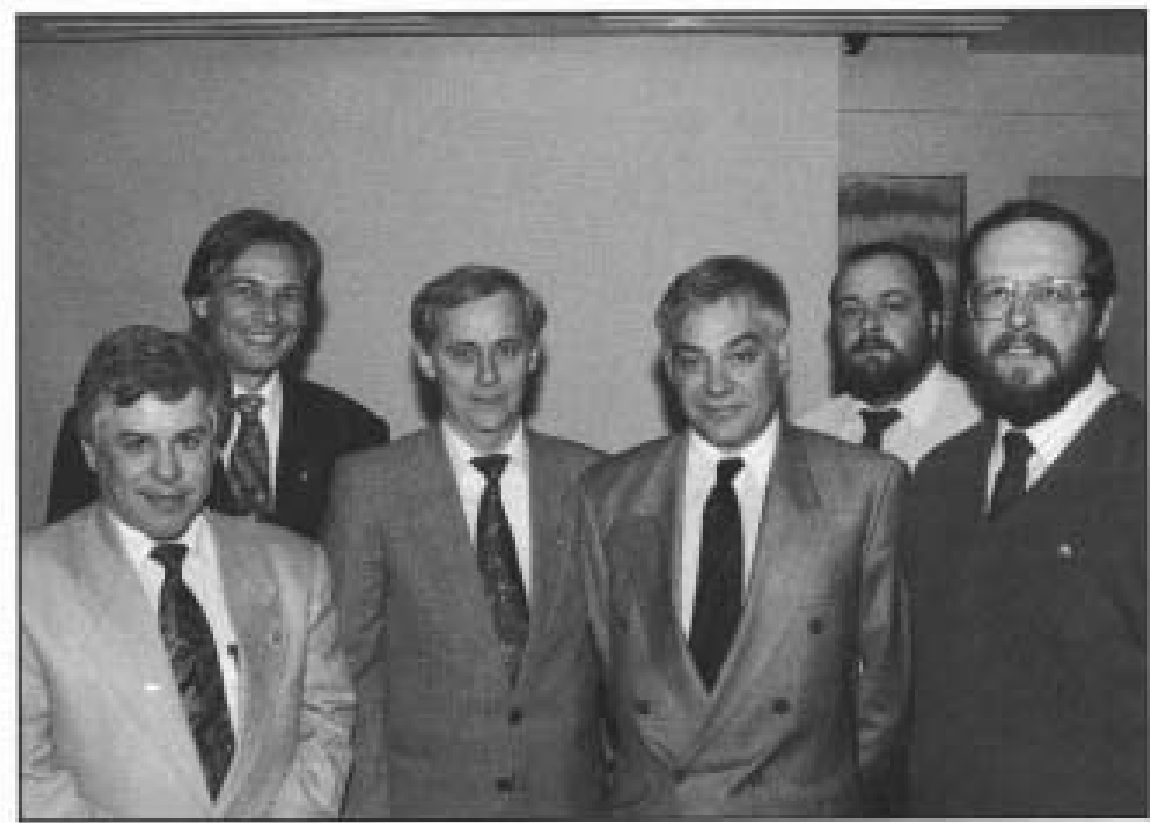

De ganche à droite, nous voyons Messieurs Régis Proslx, Ministère des Forèts du Quêbec, Luc Bouthillier, vice-president IFC Orleans, Jean Brunet, Ministère des Forêts du Québec, Gilles Frisque, Université du Québec, Robert Gagnon, directeur IFC Orléans, et Réjean Gagnon, Université du Québec à Chicoutimi.

Par la saite, M. Brunet a fait part à l'auditoire des conskquences de ces feux pour I'industrie forestiere. Malgné une importante perte de volume sur pied et une baisse de possibilité pouvant atteindre $300000 \mathrm{~m}^{3} / \mathrm{an}$, pendant 40 ans, le Ministère des Foréts poarra, selon M. Brunet, respecter ses obligations envers I'industric.

Enfin, M. Gagnon a discuté du rôle des feux dans la dynamique de la fortt bortale. Par des analyses de sédiments, l'bquipe de recherche de M. Gagnon a dejà montré que des feux sont survenus plus ou moins régulièrement depuis les 10000 dernières années dans cette région du Québec. Le feu est. selon M. Gaznon. une catastrophe

\section{Obituary}

\section{Deither E. (Doug) Buck (1928-1992)}

Deither E. (Doug) Buck died February 2 , 1992. He was born in Bandoeng, Indonesia on January 29, 1928. He emigrated to West Germany in 1948 during the Indonesian revolution and then on to Canada in 1953.

After a summer working in agriculture in Quebec, Doug started work in the logging industry in the North Bay area of Northeasiern Ontario. He worked for Howard Smith Paper Mill, J.B. Smith Lumber Lid. Lafreniere Lumber, and Gillies Bros, in positions of increasing responsibility. Doug naturelle, nécessaire au maintien de cet Écosystème nordique. La chaieur fait en effet ourvrir les cotoes dans le bouppier des vieilles épinettes. Les graines sont ainsi libetrtes et la régenération naturelle s'installe dès l'annbe qui suit le feu. Cette informa. tion est tres importante car les gestionnaires pourront connaitre, dès l'automne 1992. les aires où l'on devra procéder a des travaux de reboisement.

La séance s'est terminée par des questions et réflexions touchant la possibilité d'utiliset le feu dans certains beosystèmes forestiers nordiques

Rober R. Gagnan, ing.f., M.Sc. then returned to school at University of Toronto and graduated with a B.Sc.F. in 1963. From 1964 to 1966 he worked for Consolidated Bathhurst Lid. as a Management Forester before joining Wm. Milne and Sons Lud. of Temagami as Woodlands Manager.

As Woodlands Manager Doug helped pioneer logging operations within the Sky. line reserve of Lake Temagami. He was involved in the liaison with the Temagami Lakes Associanion and the public in general. and supervised the logging operations. He also initiated helicopeer logging trials in the Temagami area in an effort to lessen the impact of logging and logging roads on the 